\title{
PRAVNI I EKONOMSKI ASPEKTI PRAVILA UEFA-E O LICENCIRANJU KLUBOVA I FINANCIJSKOM FAIR PLAYU
}

\author{
UDK: 339. 9: 796.078 \\ Primljeno: 15. 01.2018. \\ Pregledni rad
}

\begin{abstract}
Rezultati nadzora koji je 2009. godine nad klubovima provela UEFA pokazali su da više od polovine od ukupno 655 europskih klubova posluje s gubicima. I to ogromnim gubicima, posve nesrazmjernim njihovim financijskim mogućnostima. Tri najveća europska kluba bila su u takvom financijskom rasulu da bi, da su bili tretirani kao ostali poduzetnici, bankrotirali u roku od dvije godine. Kako je to razdoblje koincidiralo s proširivanjem legislativnih ovlasti EU i na pitanja sporta i s fokusom Komisije na „dobrom upravljanju“, već 2010. godine UEFA je predstavila novi Pravilnik o licenciranju klubova i financijskom fair playu. Navedenim se Pravilnikom uvelo poslovanje na „točki pokrića“, kao temelj financijske održivosti europskih klubova, međutim, od samih početaka njegove primjene sporan je njegov odnos s odredbama prava EU o tržišnom natjecanju. U tom limbu Pravilnik egzistira već 8 godina i polako se počinju nazirati stvarni učinci njegove primjene. Pokazalo se, naime, da i pravni i ekonomski učinci nerijetko imaju neočekivani efekt, osobito u kombinaciji s pravom EU. Namjera je autorice u ovom radu detaljno promotriti odredbe Pravilnika kroz različite prizme: odnos s odredbama prava EU, njegove ekonomske učinke, utjecaj na stabilnost i kompetitivnu ravnotežu.
\end{abstract}

Ključne riječi: pravo EU, tržišno natjecanje, autonomija sporta, UEFA, financijski fair play

\section{UVOD}

Ujedinjavanjem ekonomija država članica i stvaranjem jedinstvenog tržišta, EU je nastojala stvoriti ,područje bez unutarnjih granica u kojem je osigurano slobodno kretanje dobara, osoba, usluga i kapitala" ", ${ }^{\text {s }}$ krajnjim ciljem ujednačenog ekonomskog rasta i progresivne političke integracije među državama članicama. Sloboda tržišnog natjecanja navedena je kao jedan od ključnih mehanizama ostvarivanja temeljnih tržišnih sloboda. To je vidljivo i iz čl. 101.-109. Ugovora o funkcioniranju Europske unije (dalje: UFEU) ${ }^{2}$ koji imaju zadaću osigurati jednakost tržišnog natjecanja, pa izrijekom zabranjuju narušavanje tržišnog natjecanja, ali i korištenje državnih potpora u tu svrhu. Ergo, svaki čimbenik koji sudjeluje na

1 Čl. 26. st. 2. Ugovora o funkcioniranju EU (TFEU).

2 Treaty of Lisbon, OJ C 306, od 17. XII. 2007. 
Dr. sc. Ines Medić: Pravni i ekonomski aspekti Pravila UEFA-e o licenciranju klubova i financijskom... Zbornik radova Pravnog fakulteta u Splitu, god. 55, 2/2018., str. 331.- 351.

jedinstvenom tržištu dužan je poštovati odredbe prava EU, uključujući zabranu narušavanja tržišnog natjecanja.

Za razliku od većine drugih tržišnih takmaca, sportska tijela čvrsto zastupaju izrazito protekcionističku viziju upravljanja sportom te se oslanjaju na mrežu vlastitih pravila i normativa ${ }^{3}$ koji nisu uvijek usklađeni sa zahtjevima prava EU. Sve do kraja 70-ih i 80-ih godina prošlog stoljeća, i Europsko vijeće (u daljnjem tekstu: Vijeće) i Europska komisija (u daljnjem tekstu: Komisija $)^{4}$ tretirali su sport kao posebno osjetljivo pitanje, pa je, unatoč odluci Suda EU u predmetu Walrave, ${ }^{5}$ i njihov pristup sportu bio prilično blagonaklon i više usmjeren na poticanje nego na forsiranje usklađivanja sa zahtjevima prava EU. ${ }^{6}$ Za razliku od Vijeća i Komisije, Europski parlament od početka je zagovarao oštriji pristup i tražio uklanjanje svih restrikcija slobodnom kretanju sportaša,${ }^{7}$ ali su zbog nenadležnosti njegovi zahtjevi ostali neuslišeni. ${ }^{8}$ Tek nakon odluke Suda EU u predmetu Bosman ${ }^{9}$ i inicijalnog šoka koji je u sportskim krugovima nedvojbeno izazvala, međunarodne sportske organizacije počele su percipirati mogući utjecaj prava EU na profesionalni sport. ${ }^{10}$ Nakon razdoblja neumjerenog kriticizma, nastupilo je razdoblje intenzivnog lobiranja međunarodnih sportskih organizacija u smjeru reduciranja regulatornih

3 Parish, R.: Sports Law and Policy in the European Union, Manchester University Press, 2003., str. 2015.-2016.

4 European Commission: The European Community and Sport. Communication from the Commmission to the Council and the European Parliament, SEC (91) 1438 final, od 31. VII. 1991.

5 Kojom je vrlo jasno definiran stav Suda EU da sport, dok god predstavlja ekonomsku aktivnost, potpada pod polje primjene Ugovora, a sportska praksa mora udovoljavati zahtjevima europskoga prava. Case 36/74 Walrave and Koch v. Association Union Cycliste Internationale and Others (1974) ECR 1405.

6 Barani, L.: The Role of the European Court of Justice as a Political Actor in the Integration Process: The Case of Sport Regulation after the Bosman Ruling, Journal of Contemporary Research 1(1), 2005., str. 46.

7 European Parliament: Resolution of the European Parliament on Sport in the Commmunity, Rapporteur: A. Bord. OJ C 127/1984; Resolution of the European Parliament on Sport in the European Community and a People's Europe, Rapporteur: J. Larive. OJ C 69/1989; Resolution of the European Parliament on the Freedom of Movement of Professional Football Players in the Community, Rapporteur: J.L. Janssen van Raay. OJ C 120/1989; The European Community and Sport. Committee on Culture, Youth and the Media. Rapporteur: J. Larive. A3-0326/94.

8 Parrish, R.: The Birth of European Union Sports Law, Entertainment Law, 2(2), 2003., str. 65.

9 C-415/93 Union Royale Belge des Sociétés de Football Association ASBL $v$ JeanMarc Bosman (1995) ECR I-4921.

10 Garcia, B.: UEFA and the European Union: From Confrontation to Cooperation, Journal of Contempoorary European Research, 3(3), 2007., str. 209.; Parrish, R./McArdle, D.: Beyond Bosman: The European Union's influence upon professional athletes' freedom of movement, Sport in Society, 7(3), 2004., str. 441. 
Dr. sc. Ines Medić: Pravni i ekonomski aspekti Pravila UEFA-e o licenciranju klubova i financijskom... Zbornik radova Pravnog fakulteta u Splitu, god. 55, 2/2018., str. 331.- 351.

aktivnosti tijela EU, ${ }^{11}$ koje je naišlo na određeno razumijevanje od strane tijela EU, ${ }^{12}$ ali ne i na isključivanje sporta iz zakonodavnih aktivnosti europskog zakonodavca. ${ }^{13}$

Danas je nesporno i opće po(pri)znato da je autonomija sporta, osim u segmentu stricto sensu sportskih pravila (pravila igre) i to gotovo isključivo onih koja ne proizvode nikakve ekonomske učinke,$^{14} \mathrm{u}$ određenoj mjeri ograničena heteronomnim pravom. Na području EU to su odredbe nacionalnih zakonodavstava te relevantnih međunarodnih izvora, prvenstveno prava EU. Granice te autonomije određene su ne samo pravnim aktima, nego i bogatom praksom Suda EU, osobito u području tržišnih sloboda. Iz te prakse jasno proizlazi da su određene prepreke odnosno ograničenja tržišnih sloboda dopuštena isključivo onda kada su ,imanentna organizaciji i pravilnom upravljanju natjecateljskim sportom“ i proporcionalna cilju koji se njima nastoji ostvariti. ${ }^{15} \mathrm{U}$ tom smislu, i svaki akt neke sportske federacije podložan je testu sukladnosti s pravom EU, te eventualnim ograničenjima ako se utvrdi da svojim odredbama ugrožava neku od temeljnih sloboda. Jedan od takvih akata svakako je i Pravilnik UEFA-e o licenciranju klubova i financijskom fairplayu (u daljnjem tekstu: Pravilnik). ${ }^{16}$

\section{POLOŽAJ SPORTA U PRAVU EU}

Do 2009. godine temelj pravnog normiranja sporta na području EU činile su odluke Suda EU i Europske komisije te brojni akti soft lawa ${ }^{17}$ kojima se Zajednicu poziva da različitim odredbama Ugovora uzme u obzir karakteristike amaterskog

11 Vidi: Infantino, G.: Meca-Medina: a step backwards for the European Sports Model and the Specificity of Sport?, UEFA, 2006., preuzeto sa: http://www.uefa.com/MultimediaFiles/Download/uefa/ KeyTopics/480391_DOWNLOAD.pdf; IOC and FIFA Joint Declaration - EU white paper on sport: Much work remains to be done, preuzeto sa: http://www.olympic.org/nwes?articleid=54916; Niemann, A./Brand, A.: The impact of European integration on domestic sport: the case of German football. Sport in Society: cultures, commerce, media, politics, 1(1), 2008., str. 98.

12 Vidi: European Parliament: Resolution of 8 May on the White Paper on Sport, INI/2007/2261.

13 Geeraert, A.: Limits to the autonomy of Sport: EU law, Action for Good Governance in International Sports Organizations (AGGIS), HIVA - Research Institute for work and society, KU Leuven. Dostupno na: http://www.playthegame.org/fileadmin/documents/AGGIS_Geeraert_-_Limits_to_the_autonomy_ of_sport.pdf.

14 Konkretne primjere takvih pravila vidi u: European Commission: The EU and Sport: Background and Context, Accompanying document to the White Paper on Sport, SEC(2007) 935 final.

15 Vidi: Vöpel, H.: Is Financial Fair Play really justified? An economic and legal assesment of UEFA's Financial Fair Play rules, HHWI Policy Paper, No. 79, 2013., str. 23. Vidi i: White Paper on Sport, op. cit. (bilj. 18.), str. 64.

16 Dostupno na: http://hns-cff.hr/files/documents/9388/HNS\%20Pravilnik\%20o\%20licenciranju $\% 20$ 2015.pdf.

17 Primjerice: Deklaracija iz Amsterdama (1997.) uz Ugovor iz Amsterdama (Treaty of Amsterdam, The Declaration on Sport, OJ C 340, od 10. XI. 1997.), Deklaracija iz Nice (2000.) uz Ugovor iz Nice (Treaty of Nice amending the Treaty on European Union, the Treaties establishing the European Communities and certain related acts, signed by European leaders on 26 February 2001 and came into force on 1 February 2003. It amended the Maastricht Treaty (or the Treaty on European Union) and the Treaty of Rome (or the Treaty establishing the European Community), OJ C 80, od 10. III. 2001.), te Deklaracija iz Aarhausa (2003.) (The Aarhaus Declaration on Voluntary Work in Sport, http://kum. 
Dr. sc. Ines Medić: Pravni i ekonomski aspekti Pravila UEFA-e o licenciranju klubova i financijskom... Zbornik radova Pravnog fakulteta u Splitu, god. 55, 2/2018., str. 331.- 351.

sporta, socijalnu, odgojnu i kulturnu funkciju sporta, te potrebu očuvanja dobrovoljne organizacijske strukture. ${ }^{18}$ Međutim, unatoč postojanju brojnih soft law dokumenata, prije stupanja na snagu Ugovora iz Lisabona, 1. prosinca 2009. godine,${ }^{19}$ EU nije imala eksplicitne ovlasti u sferi sporta. ${ }^{20}$ Štoviše, u Ugovoru o EZ ${ }^{21}$ sport nije niti spomenut. Unatoč tome, Sud EU nije prihvatio ideju o razdvojenosti upravljanja sportom od prava EZ. ${ }^{22}$ Umjesto toga, dosljedno je zauzimao stav da dok god predstavlja ekonomsku aktivnost, sport potpada pod polje primjene Ugovora, a sportska praksa mora udovoljavati zahtjevima europskog prava. Dakle, iako je Zajednici bila uskraćena konkretna legislativna nadležnost u sferi sporta, odredbe o slobodi kretanja, tržišnom natjecanju te zabrani diskriminacije temeljem državljanstva ostavljale su dovoljno prostora i za ostvarivanje takvih ovlaštenja. ${ }^{23}$

Tek navedenim Ugovorom iz Lisabona (Ugovorom o funkcioniranju Europske unije, UFEU $)^{24}$ prvi je put u povijesti EU izrijekom propisana nadležnost tijela EU $\mathrm{u}$ sferi sporta ${ }^{25}$ a pitanje odnosa autonomije sporta i prava EU stavljeno je u fokus. Stavkom 1. čl. 165. UFEU-a određeno je da će Unija doprinositi promicanju pitanja europskog sporta, uzimajući u obzir specifičnu prirodu sporta, njegovu strukturu utemeljenu na voluntarizmu te njegovu društvenu i odgojnu ulogu, ${ }^{26}$ dok se st. 4 . ovlašćuju institucije Unije na donošenje poticajnih mjera i preporuka. Međutim, ne slažu se svi oko novostečenih kompetencija Unije. Tako Weatherill dvoji o formalnoj nadležnosti Unije za sport u odnosu na nadležnost tijela koja upravljaju sportom. On smatra da čl. 165. UFEU-a „sasvim sigurno ne dozvoljava Uniji da uzurpira dosadašnji položaj tijela koja upravljaju sportom u odnosu na njihov preferirani sustav upravljanja“. ${ }^{27} \mathrm{Za}$ razliku od toga, Parrish smatra da „europsko sportsko pravo sportu priznaje prostor samoregulacije u okviru lex sportiva, ali uvjetuje njegovu autonomiju prihvaćanjem integracije temeljnih načela prava, kao

dk/nyheder-og-presse/pressemeddelelser/2002/november/eu-sportsministerkonference-i-aarhus-21-22november/the-aarhus-declaration-on-voluntary-work-in-sport/ , 5. VII. 2015.).

18 European Commission, White Paper on Sport, COM (2007) 391 final, par. 3.2.2.

19 Vidi bilj. 2.

20 C̆l. 165. Ugovora iz Lisabona navodi: „The Union shall contribute to the promotion of European sporting issues while taking into account of its specific nature, its structures based on voluntary activity and its social and educational function".

21 Treaty of Amsterdam amending the Treaty on European Union, the Treaties establishing the European Communities and Related Acts, Sl. 1. EZ C 340, od. 10. XI. 1997.

22 Vidi: Case 36/74 Walrave and Koch v. Association Union Cycliste Internationale and Others (1974) ECR 1405. Weatherill, S. et alii.: European Sports Law, Asser International Sports Law Series, T.M.C. Asser Press, The Hague, 2014., str. 508.

23 Ibidem.

${ }^{24}$ Consolidated version of the Treaty on the Functioning of the European Union, S1. 1. EU C 83, od 30. III. 2010.

25 Vidi čl. 6. UFEU-a.

26 Više o tome vidi u: Weatherill, S.: Fairness, „Openess and the Specific Nature of Sport: Does the Lisbon Treaty Change EU Sports Law?", The International Sports Law Journal, 3-4/2010, str. 11.-17.

27 Weaterill, S.: „Is there such a thing as EU sports law?“, International Sports Law Journal, 1-2, 2011, str. 38. 
Dr. sc. Ines Medić: Pravni i ekonomski aspekti Pravila UEFA-e o licenciranju klubova i financijskom... Zbornik radova Pravnog fakulteta u Splitu, god. 55, 2/2018., str. 331.- 351.

što su to proporcionalnost i dobro upravljanje, u sadržaj lex sportiva“ ${ }^{28}$ Ovo drugo tumačenje u svakom slučaju više odgovara viđenju vlastite nadležnosti od strane tijela EU.

\section{PRAVILNIK O LICENCIRANJU KLUBOVA I FINANCIJSKOM FAIR PLAYU}

U svojim počecima upravljanje nogometom bilo je isključivo na nacionalnoj razini, putem nacionalnih saveza, da bi se tek s vremenom prebacilo na međunarodne federacije kao što su FIFA (1904.) i UEFA (1954.). U to vrijeme i upravljanje nogometom, financijsko i organizacijsko, bilo je uglavnom ograničeno na nacionalnu razinu, a glavni izvor prihoda bila je prodaja ulaznica. ${ }^{29} \mathrm{U}$ usporedbi s tadašnjom situacijom, današnji nogometni pejzaž znatno se razlikuje. Jedan od ključnih faktora ekonomske ekspanzije nogometa uvjetovan je golemim prihodima proizašlim iz televizijskih prava nacionalnih, u pravilu monopolističkih, kuća. ${ }^{30}$ Pored prihoda od medija i ekonomske aktivnosti, značajan dio prihoda donose i bogati privatni ulagači u klubove, transferi nogometaša itd. Poslovanje nogometnih klubova današnjice više nalikuje poslovanju neke transnacionalne kompanije. ${ }^{31}$

Problem je, međutim, što većina klubova posluje u minusu. Ili riječima trenutnog predsjednika FIFA-e Giannija Infantina: „Moramo zaustaviti negativnu spiralu klubova koji proizvode gubitke i imaju goleme dugove. Ako sad ne počnemo djelovati, mogli bismo imati krizu sličnu onoj koja je pogodila europsku ekonomiju u cjelini.“..32 Istu zabrinutost dugo je izražavao i bivši predsjednik UEFA-e Michel Platini, koji je višekratno naglašavao da većina klubova akumulira dugove ili se, pak, oslanjaju na financijske injekcije bogatih vlasnika te tako, svojom financijskom neodgovornošću, stječu nepoštenu prednost. ${ }^{33}$ Uzrok dugova identificiran je, uglavnom, u primanjima nogometaša i troškovima njihova transfera. Također i u zaduživanju s ciljem bolje prolaznosti na europskim natjecanjima te, posljedično tome, boljim prihodima. ${ }^{34}$

$\mathrm{Na}$ navedene probleme UEFA je pokušala odgovoriti još 2003. godine uvođenjem brojnih regulatornih postupaka u sklopu licenciranja klubova, uvedenog

28 Parrish, R.: „Lex sportiva and EU sports law“, Law Review, 37(6), 2012., str. 716.

29 Marks, J.: UEFA, the EU and Financial Fair Play. ,On ne dépense pas plus d'argent que i'on n'en génère! “, Politique européene 2012/1 (no 36), str. 54.; Raballand, G./Cianferani, S./Marteau, J.-F.: Quel avenir pour le football? Objetif 0-0, L'Harmattan, Paris, 2008., str. 31.

${ }^{30}$ O izazovima koji su se javili ulaskom u EU vidi: Szymanski, S.: Football Economics and Policy, Palgrave MacMillan, 2010., str. XV.; Marshall, P./Tomlin, S.: Football and the Big Society. Preuzeto sa: www.cetreforu.org/assets/pubs/football-and-the-big-society.pdf.

31 Marks, op. cit. (bilj. 28.), str. 55.

32 Conn, D.: „Uefa to Penalise Clubs who Break Financial Rules“, The Guardian, no. 26, January 2012., str. 46.

33 UEFA 2010.

34 Tako: Szymanski, op. cit. (bilj. 30), str. 156.-170. 
Dr. sc. Ines Medić: Pravni i ekonomski aspekti Pravila UEFA-e o licenciranju klubova i financijskom... Zbornik radova Pravnog fakulteta u Splitu, god. 55, 2/2018., str. 331.- 351.

na inicijativu Europskog parlamenta. ${ }^{35}$ Naglasak koji je u tom periodu EU stavila na „dobro upravljanje“ potakao je, već 2008. godine, osnivanje UEFA-ina Povjerenstva za socijalni dijalog u europskom profesionalnom nogometu, za pregovore između regulatora (UEFA-e) i klubova, liga, igrača. Nedugo nakon toga, 2010. godine, UEFA je predstavila Pravilnik o licenciranju klubova i financijskom fair-playu, ${ }^{36}$ koji je zapravo unaprijeđena verzija ranijeg UEFA-inog Pravilnika o licenciranju klubova. Pravilnik se odnosi samo na one klubove koji se kvalificiraju za klupska natjecanja koja se organiziraju pod nadležnošću UEFA-e.

Šest temeljnih ideja sadržanih u Pravilima:

- poboljšati ekonomsku i financijsku sposobnost klubova, povećati njihovu transparentnost i vjerodostojnost;

- dati poseban značaj zaštiti vjerovnika na način da klubovi pravovremeno podmiruju svoje obveze prema zaposlenicima i državi za poreze i doprinose, te drugim klubovima;

- uvesti više discipline i racionalnosti u financijsko poslovanje klubova;

- $\quad$ poticati klubove da posluju na osnovi svojih vlastitih prihoda;

- poticati odgovornu potrošnju na dugoročnu dobrobit nogometa;

- poticati dugoročnu racionalnost i održivost europskog klupskog nogometa. ${ }^{37}$

Pored revidiranih odredbi ranijih kriterija za licenciranje, Pravilnik uvodi i nove kriterije u financijski fair-play. Međutim, za razliku od licenciranja, Pravilnik predviđa da monitoring klubova provodi izravno UEFA, odnosno UEFA-ino Tijelo za financijsku kontrolu klubova. ${ }^{38}$ To je tijelo sastavljeno od eksperata kvalificiranih za pravna i ekonomska pitanja. Sam Pravilnik ne propisuje izrijekom neku specifičnu vrstu sankcija, ali čl. 72. (Disciplinski postupci) za svako kršenje odredbi ovog Pravilnika upućuje na mogućnost sankcioniranja sukladno odredbama Pravilnika UEFA-e o postupcima tijela UEFA-e za financijsku kontrolu klubova (2012.). ${ }^{39}$ Uvidom u odredbe Pravilnika UEFA-e o postupcima tijela UEFA-e za financijsku kontrolu klubova, konkretno njegov čl. 21. st. 1., razvidno je da disciplinske mjere mogu uključivati: opomenu, ukor, novčanu kaznu, oduzimanje bodova, zadržavanje

35 Besson, É: Accroître la compétitivité du football professionnel français, novembre 2008, str. 57. Dostupno na: http://sport.event.free.fr/Docs/rapport\%20Ministres/rapportbesson.pdf, prema: Marks, op. cit. (bilj. 28), str. 63.

36 Vidi bilj. 16.

37 Čl. 2. st. 2. Pravilnika. Isto i Pravilnik HNS-a o licenciranju klubova, studeni 2015., čl. 2, dostupno na: http://hns-cff.hr/files/documents/9388/HNS\%20Pravilnik\%20o\%20licenciranju\%202015.pdf.

38 Čl. 53. i 54. Pravilnika.

39 Dostupno na http://hns-cff.hr/files/documents/old/771-UEFA\%20Pravilnik\%20o\%20 postupcima $\% 20$ Uefinog $\% 20$ Tijela\%20za\%20financijsku\%20kontrolu\%20klubova\%20-\%20\%20 izdanje \%202012.pdf. 
Dr. sc. Ines Medić: Pravni i ekonomski aspekti Pravila UEFA-e o licenciranju klubova i financijskom... Zbornik radova Pravnog fakulteta u Splitu, god. 55, 2/2018., str. 331.- 351.

prihoda od natjecanja EUFA-e, zabranu registracije novih igrača u natjecanja UEFA-e itd.

Kao temeljni element kontrole klubova uveden je zahtjev da budu na nuli (tzv. točka pokrića) (break even requirement). Člankom 58. Pravilnika definirani su relevantni prihodi i rashodi, koje je potrebno „,izračunati i uskladiti s godišnjim financijskim izvještajima i/ili temeljnim računovodstvenim podacima, tj. povijesnim, aktualnim ili budućim financijskim podacima, već što je prikladno“. Razlika između relevantnih prihoda i relevantnih rashoda predstavlja točku pokrića.

S ciljem poticanja ulaganja u stadione i druge objekte za treniranje, razvoj nogometnog podmlatka i ženski nogomet (od 2015. godine), svi takvi troškovi su isključeni iz kalkulacije točke pokrića ${ }^{40}$ Riječ je o potencijalno veoma važnim iznimkama koje ostavljaju prostora u smislu kvalifikacije pojedinog troška kao relevantnog rashoda ili iznimke. U tom smislu, za očekivati je da će s vremenom klubovi razviti različite sheme izbjegavanja kvalificiranja određenih rashoda kao relevantnih. U tom smjeru ide i odredba st. 4. čl. 58. Pravilnika koja eksplicitno navodi da se ,relevantni prihodi i rashodi povezanih strana moraju prilagoditi na način da odražavaju fer vrijednost u svakoj od takvih transakcija“.

Člankom 61. Pravilnika definirano je i tzv. ,prihvatljivo odstupanje“ od točke pokrića. Radi se o „najvišem mogućem zbirnom deficitu točke pokrića koji klub može imati, a da bi se smatralo da ispunjava zahtjev točke pokrića“. Navedena se odredba počela primjenjivati od momenta stupanja Pravilnika na snagu, dakle od sezone 2013./14., a kao iznos prihvatljivog odstupanja naveden je iznos od 5 milijuna eura. Međutim, ukoliko je odstupanje u cijelosti pokriveno ulozima kapitalnih ulagača i/ili povezanih strana u natjecateljskim sezonama 2013./14. i 2014./15. moglo je premašivati ovu razinu do iznosa od 45 milijuna eura, a u natjecateljskim sezonama 2015./16., 2016./17. i 2017./18. do 30 milijuna eura. Intencija je Pravilnika da se $\mathrm{s}$ vremenom primjenjuje još rigoroznije. To je razvidno i iz ostalih zahtjeva, ${ }^{41} \mathrm{koji}$ uključuju dostavu budućih financijskih podataka, dokaz o tome da nema dospjelih obveza prema drugim nogometnim klubovima te zaposlenicima i/ili državi i obvezu izvještavanja o svim značajnim ekonomskim promjenama do kraja licencirane natjecateljske godine.

„Razdoblje pod nadzorom“ trogodišnje je razdoblje tijekom kojeg se primatelja licence procjenjuje u svrhu zahtejva točke pokrića.${ }^{42}$ Od nadzora su izuzeti: ${ }^{43} \mathrm{klubovi}$ koji se kvalificiraju u UEFA-ino klupsko natjecanje na osnovi sportskog rezultata i koji imaju posebno odobrenje, ${ }^{44}$ te primatelji licence koji iskažu relevantne prihode

40 UEFA: Financial Fair Play: all you need to know, 30 June 2015., str. 1., dostupno na: http://www. uefa.com/community/news/newsid=2064391.html.

41 Čl. 64.-68. Pravilnika.

42 Uključuje: izvještajno razdoblje koje završava na kraju kalendarske godine u kojoj započinju klupska natjecanja UEFA-e, izvještajno razdoblje koje završava u kalendarskoj godini prije početka klupskih natjecanja UEFA-e, te prethodno izvještajno razdoblje. Čl. 59. st. 1. Pravilnika.

43 Čl. 57. Pravilnika.

44 Temeljem čl. 15. Pravilnika. 
Dr. sc. Ines Medić: Pravni i ekonomski aspekti Pravila UEFA-e o licenciranju klubova i financijskom... Zbornik radova Pravnog fakulteta u Splitu, god. 55, 2/2018., str. 331.- 351.

i relevantne rashode manje od 5 milijuna eura u odnosu na svako od dva izvještajna razdoblja koja su završila dvije godine prije početka klupskih natjecanja UEFA-e.

\section{UREĐENJE TRŽIŠNOG NATJECANJA NA EUROPSKOJ RAZINI}

Materija koja se tiče tržišnog natjecanja uređena je Glavom VII. UFEU-a, pod nazivom „Zajednička pravila o tržišnom natjecanju, oporezivanju i usklađivanju zakonodavstava““. ${ }^{45}$ Za tržišno natjecanje relevantni su čl. 101., koji zabranjuje sporazume ili odluke koje mogu spriječiti, ograničiti ili narušiti tržišno natjecanje, te komplementarni čl. 102., čiji je predmet zlouporaba dominantnog položaja na tržištu, koji utječe na učinkovito natjecanje.

Članak 101. (bivši čl. 81. UEZ-a) st. 1. UFEU-a ${ }^{46}$ zabranjuje direktno ili indirektno fiksiranje bilo prodajne bilo kupovne cijene. Zbog nespojivosti s unutarnjim tržištem, zabranjuje sve sporazume ili odluke koje mogu limitirati investicije, odnosno koje mogu negativno utjecati na trgovinu među državama članicama i koje imaju za cilj ili rezultiraju ,sprečavanjem, ograničavanjem ili narušavanjem tržišnog natjecanja na unutarnjem tržištu“. Sporazum, odluka ili usklađeno djelovanje koje narušava tržišno natjecanje ništetni su i nije ih moguće provesti, osim ako je riječ o izuzeću. ${ }^{47}$ Izuzeci su normirani st. 3. čl. 101. UFEU-a, ${ }^{48}$ a mogući su samo uz ostvarivanje

45 Konkretnije, u pitanju je Poglavlje 1. Pravila o tržišnom natjecanju te Odjeljak 1., Pravila koja se primjenjuju na poduzetnike.

46 Čl. 101. st. 1. UFEU-a: Budući da su nespojivi s unutarnjim tržištem, zabranjuju se: svi sporazumi među poduzetnicima, odluke udruženja poduzetnika i usklađeno djelovanje koje bi moglo utjecati na trgovinu među državama članicama i koji imaju za cilj ili posljedicu sprečavanje, ograničavanje ili narušavanje tržišnog natjecanja na unutarnjem tržištu, a osobito oni kojima se:

(a) neposredno li posredno utvrđuju kupovne ili prodajne cijene ili drugi trgovinski uvjeti;

(b) ograničuju ili nadziru proizvodnja, tržišta, tehnički razvoj ili ulaganja;

(c) vrši podjela tržišta ili izvora nabave;

(d) primjenjuju nejednaki uvjeti na istovrsne poslove s ostalim trgovinskim partnerima, čime ih se stavlja u nepovoljan položaj u odnosu na konkurenciju;

(e) sklapanje ugovora uvjetuje preciziranjem dodatnih obveza od strane drugih stranaka koje, po svojoj naravi ili prema običajima u trgovini, nisu ni u kakvoj vezi s predmetom tih ugovora.

47 Čl. 101. st. 2. UFEU-a - Svi sporazumi ili odluke zabranjeni na temelju ovoga članka ništavi su.

48 Čl. 101. st. 3. UFEU-a - Međutim, odredbe stavka 1. mogu se proglasiti neprimjenjivima u slučaju:

- svakog sporazuma ili vrste sporazuma među poduzetnicima,

- svake odluke ili vrste odluka udruženja poduzetnika,

- svakog usklađenog djelovanja ili vrste usklađenog djelovanja koji doprinose poboljšanju proizvodnje ili distribucije robe ili promicanju tehničkog ili gospodarskog napretka, a istodobno potrošačima omogućuju pravedan udio u koristi koja iz njih proizlazi te koji:

(a) tim poduzetnicima ne nameću ograničenja koja nisu nužna za postizanje ovih ciljeva;

(b) tim poduzetnicima ne omogućuju isključivanje konkurencije s tržišta s obzirom na znatan dio dotičnih proizvoda. 
Dr. sc. Ines Medić: Pravni i ekonomski aspekti Pravila UEFA-e o licenciranju klubova i financijskom... Zbornik radova Pravnog fakulteta u Splitu, god. 55, 2/2018., str. 331.- 351.

određenih uvjeta, ponajprije u slučajevima kad protržišni učinci nadilaze antitržišne učinke. ${ }^{49}$

Čl. 102. (bivši čl. 82. UEZ-a) ${ }^{50}$ zabranjuje svaku zlouporabu od strane jednog ili više poduzetnika koji dominiraju tržištem. ${ }^{51}$ Iz prakse Suda EU proizlazi da se dominacija kvalificira kao „pozicija ekonomske moći koju uživa poduzetnik, ili više njih, a koja mu omogućuje da sprečava učinkovito tržišno natjecanje na relevantnom tržištu ${ }^{52}$ i daje mu moć da se u značajnoj mjeri ponaša neovisno o drugim natjecateljima, potrošačima ili čak i vlastitim potrošačima“ ${ }^{53}$ Dakle, radi se o očitoj dominaciji na unutarnjem tržištu koja ima potencijal utjecati i na razmjenu među državama članicama. Poduzetnik čiji je tržišni udio manji od $40 \%$ teško bi se mogao smatrati dominantnim..$^{54}$ Međutim, ako je njegov tržišni udio $50 \%$ ili više, vrijedi oboriva presumpcija njegove dominacije. ${ }^{55}$

Ugovorom o funkcioniranju EU, uloga nadzornog tijela dodijeljena je Komisiji. Komisija je ovlaštena istražiti svako ponašanje koje može ugrožavati slobodu tržišnog natjecanja. Po potrebi, može inicirati postupak protiv države članice koja u svoje nacionalno zakonodavstvo nije implementirala odredbe europskog zakonodavstva (, guardian of the Treaties" ${ }^{\text {") }},{ }^{56}$ a također može i ,nadgledati primjenu prava EU pod kontrolom Suda EU“ “. ${ }^{57}$ Iz teksta odredaba UFEU-a očito je da je taj nadzor usmjeren prema državama članicama, odnosno njenim javnim tijelima ili privatnim tijelima pod nadzorom javnih tijela, čija aktivnost ili propust može

49 Hickey, M.: Are UEFA's Financial Fair Play rules at odds with EU Competition Law?, 20 August 2004., preuzeto sa: https://www.lexology.com/library/detail.aspx?g=b8526948-4560-4425-9e48e2af69a8414a.

50 Čl. 102. UFEU-a - Svaka zlouporaba vladajućeg položaja od strane jednog poduzetnika ili više njih na unutarnjem tržištu ili njegovom znatnom dijelu zabranjena je kao nespojiva s unutarnjim tržištem $u$ mjeri u kojoj bi mogla utjecati na trgovinu među državama članicama. Takva se zlouporaba može osobito sastojati od:

(a) neposrednog ili posrednog nametanja nepravednih kupovnih ili prodajnih cijena ili drugih nepravednih trgovinskih uvjeta;

(b) ograničavanja proizvodnje, tržišta ili tehničkog razvoja na štetu potrošača;

(c) primjene nejednakih uvjeta na istovrsne poslove s ostalim trgovinskim partnerima, čime ih se stavlja u nepovoljan položaj u odnosu na konkurenciju;

(d) uvjetovanja sklapanja ugovora preuzimanjem dodatnih obveza od strane drugih stranaka koje, po svojoj naravi ili prema trgovačkoj praksi, nisu ni u kakvoj vezi s predmetom tih ugovora.

51 Primjerice forsiranje potrošača da kupuju paket proizvoda u situaciji kad ih je moguće prodavati i odvojeno ili isključivanje drugih tržišnih faktora sklapanjem isključivih sporazuma. Više o tome vidi u: Reinisch, A.: Essentials of EU Law, 2nd edn. Cambridge: Cambridge University Press, 2012., str. 199; O'Leary, L.: ,Regulating the employment relationship in professional team sports“, Industrial Law Journal, 41 (2), 2012.

52 Dakle, bitno je prethodno utvrditi koje je to relevantno tržište te postoji li dominantan čimbenik na tom tržištu. Više o tome vidi u: Reinisch, op. cit. (bilj. 48).

53 Sud EU, C 27/76 United Brands Company v Commission (1978) ECR 207, para 65.

54 Geeraert, op. cit. (bilj. 13), str. 17.

55 Vidi odluku Suda EU u predmetu C-62/86 Akzo Chemie BV v. Commission (1991) ECR I-3359, para. 60 .
56 Čl. 258. UFEU-a.
57 Čl. 17. st. 1. UFEU-a. 
Dr. sc. Ines Medić: Pravni i ekonomski aspekti Pravila UEFA-e o licenciranju klubova i financijskom... Zbornik radova Pravnog fakulteta u Splitu, god. 55, 2/2018., str. 331.- 351.

dovesti do povrede prava EU. Kako su sportske federacije u pravilu privatna tijela, sa sjedištem na području Švicarske i kao takva podložna švicarskom pravu, protiv njih nije moguće postupati izravno. Moguće je, međutim, postupati neizravno, pokretanjem postupka protiv određene države članice koja je u svoje zakonodavstvo implementirala odredbe akata sportskih federacija i čija sportska tijela nastupaju kao javna tijela ${ }^{58}$ To može po vlastitom saznanju dakle (ex officio), ali i na traženje države članice ili bilo koje druge osobe s pravnim interesom. ${ }^{59}$ Međutim, iz Odluke Općeg suda u predmetu BEMIM ${ }^{60}$ razvidno je da taj interes treba i dokazati. Dakle, treba dokazati da je podnositelj zahtjeva netržišnim ponašanjem poduzetnika već doveden ili će biti doveden u nepovoljan položaj. Isto vrijedi i u slučaju podnošenja zahtjeva protiv bilo koje sportske federacije koju je, u smislu prava EU, moguće smatrati poduzetnikom ili udruženjem poduzetnika.

Člankom 258. UFEU-a ${ }^{61}$ propisana je i procedura, a uključuje davanje mogućnosti državi članici da korigira svoje postupanje i tako izbjegne pokretanje postupka pred Sudom EU, odnosno da svoje postupanje pokuša obraniti pred Komisijom. ${ }^{62}$ Ukoliko u tome ne uspije, pokreće se postupak pred Sudom EU.63

Dakle, i u segmentu tržišnog natjecanja, Komisija je nadležna pratiti poštuju li poduzetnici odredbe prava EU (o tržišnom natjecanju) ${ }^{64} \mathrm{U}$ određenim sektorima praćenje politike tržišnog natjecanja ima dugu tradiciju, dok u ostalim sektorima, kao što je sport, to nije nužno slučaj. Međutim, u novije vrijeme pojačana je kontrola i u tom sektoru. Tako je npr. u rujnu 2016. godine Komisija obavijestila Međunarodnu klizačku federaciju (ISU) o usvajanju preliminarnog stanovišta da se pravilima ISU-a koja se odnose na neovlašteno sudjelovanje u natjecanjima u brzom klizanju potencijalno krše antimonopolska pravila EU. ${ }^{65}$

58 Vidi: Geeraert, op. cit. (bilj. 13), str. 39.

59 Čl. 7. st. 2. Uredbe Vijeća (EZ) br. $1 / 2003$.

60 Opći sud, T-144/92 BEMIM v. Commission (1995) ECR II-147.

${ }^{61}$ Čl. 258. UFEU-a - Ako smatra da neka država članica nije ispunila neku obvezu na temelju Ugovora, Komisija o tom predmetu, nakon što je dotičnoj državi dala priliku da se očituje, daje obrazloženo mišljenje.

Ako dotična država ne postupi u skladu s mišljenjem u roku koji odredi Komisija, Komisija taj predmet može uputiti Sudu Europske unije.

62 Sud EU, C-282/95P Guèrin (1997) ECR I-1503, Opći sud T-127/98 UPS Europe SA v Commission (1999) ECR II-2633.

63 Sud EU, C-26/76 Metro v Commission (1977) ECR 1875.

${ }_{64}$ Čl. 4. Uredbe Vijeća (EZ) br. 1/2003 od 16. prosinca 2002. o provedbi pravila o tržišnom natjecanju koja su propisana člancima 81. i 82. Ugovora o EZ (Tekst značajan za EGP), Sl. 1. EZ L 001/1, od 16. XII. 2002.

${ }^{65}$ Predmet AT.40208 40208 Pravila prihvatljivosti Međunarodne klizačke federacije, vidi: IP/16/3201 od 27. rujna 2016., dostupan na http://europa.eu/rapid/press-release_IP-16-3201_en.htm. Ključno je pitanje ograničava li se, strogim kaznama koje mogu dovesti i do doživotne zabrane sudjelovanja u ključnim natjecanjima u brzom klizanju, komercijalna sloboda sportaša. Također, ograničava li se time ulazak novih organizatora međunarodnih natjecanja u brzom klizanju na tržište. 
Dr. sc. Ines Medić: Pravni i ekonomski aspekti Pravila UEFA-e o licenciranju klubova i financijskom... Zbornik radova Pravnog fakulteta u Splitu, god. 55, 2/2018., str. 331.- 351.

Prema prošlogodišnjem Izvješću Komisije, ${ }^{66}$ „, ciljem ostvarivanja punog potencijala jedinstvenog tržišta, Komisija je nedavno pojačala napore koje ulaže u djelotvorno provođenje europskih pravila u svim područjima politike“.${ }^{67}$

\section{DOSADAŠNJA PRIMJENA ODREDABA O ZABRANI TRŽIŠNOG NATJECANJA NA PITANJA U SPORTU}

Prvi „sportski“" predmet na koji su primijenjene ${ }^{68}$ odredbe prava EU o zabrani tržišnog natjecanja datira iz 2006. godine. Radi se o predmetu Meca-Medina, ${ }^{69} \mathrm{u}$ kojem su dvojica plivača osporavali sankcije nametnute temeljem neprolaska na doping-testu. Nakon odluke o četverogodišnjoj suspenziji, koja je po žalbi smanjena na dvije godine, plivači su uložili žalbu Europskoj komisiji, pozivajući se na povredu prava EU, konkretno prava tržišnog natjecanja. Komisija je predmet odbacila, smatrajući da osporavana pravila ne potpadaju pod polje primjene UFEU-a, da bi po žalbi dospio pred Opći sud. ${ }^{70}$ Opći sud je prihvatio mišljenje Komisije da se antidoping pravila odnose isključivo na „,neekonomski aspekt sporta“ ${ }^{71}$ no po daljnjoj žalbi Sud EU je odbacio ovakvo razmišljanje i utvrdio da je „očito da sama činjenica da je određeno pravilo po svojoj prirodi čisto sportsko pravilo ne proizvodi učinak eliminiranja iz polja primjene Ugovora osobe koja se bavi aktivnošću na koju se odnosi to pravilo, a niti tijela koje je to pravilo donijelo“. ${ }^{72}$ Sud EU je, između ostalog, utvrdio da antidoping pravila ne utječu na pravo EU o tržišnom natjecanju jer su ,neodvojiva od organizacije i pravilnog vođenja natjecateljskog sporta, a njihova je svrha osigurati zdravi rivalitet između sportaša“. ${ }^{73}$ Međutim, sankcije koje su vezane uz antidoping pravila „mogu proizvesti nepoželjne učinke na tržišno natjecanje jer mogu, ako se kazna u konačnici pokaže neopravdanom,

66 Europska komisija: Izvješće Komisije Europskom parlamentu, Vijeću, Europskom gospodarskom i socijalnom odboru i Odboru regija, Izvješće o politici tržišnog natjecanja za 2016., COM (2017) 285 final, od 31. V. 2017.

${ }^{67}$ Ibidem, str. 10. U tom pravcu ide i komunikacija „Pravo EU-a: boljom primjenom do boljih rezultata“" (dostupno na https:/ec.europa.eu/info/law/law-making-process/overview-law-making-process/ applying-eu-law_hr ).

68 Radi se o tome da se pitanje sukladnosti s čl. 101. i 102. UFEU-a moglo postaviti i u predmetu Bosman (vidi bilj. 9) iz 1995. godine, no kako to pitanje nije bilo uključeno u zahtjev za prethodnim tumačenjem upućen Sudu EU, Sud o njemu nije niti odlučivao. Međutim, to pitanje je razmatrao nezavisni odvjetnik Lenz koji je u svom Mišljenju naveo da su odredbe o transferu nogometaša u sukobu s čl. 101. UFEU-a jer ,normalan sustav ponude i potražnje zamjenjuju uniformiranom mašinerijom koja vodi očuvanju postojeće situacije“. Ograničavanjem mogućnosti transfera i nakon isteka ugovora o profesionalnom igranju ograničavaju mogućnost angažiranja igrača od strane drugih klubova, a samim time utječu i na mogućnost tržišnog natjecanja među klubovima. Opinion of Advocate General Lenz, delivered on 20 September 1995., para. 262.

\footnotetext{
69 Sud EU, C-519/04 Meca-Medina and Majcen (2006) ECR I-6991.

70 Opći sud, T-313/02 Meca-Medina and Majcen v. Commission (2004) ECR II-3291.

71 Paragraf 45. u predmetu T-313/02 Meca-Medina and Majcen v. Commission (2004) ECR II-3291.

72 Paragraf 27. u predmetu C-519/04 Meca-Medina and Majcen (2006) ECR I-6991.

73 Ibidem, paragraf 45.
} 
Dr. sc. Ines Medić: Pravni i ekonomski aspekti Pravila UEFA-e o licenciranju klubova i financijskom... Zbornik radova Pravnog fakulteta u Splitu, god. 55, 2/2018., str. 331.- 351.

rezultirati neovlaštenim isključenjem sportaša iz natjecanja, a time i narušavanjem uvjeta pod kojima se odnosna aktivnost obavlja. Odatle slijedi da... ,antidoping pravila moraju biti limitirana na ono što je neophodno da se osigura pravilno odvijanje natjecateljskog sporta". ${ }^{74}$ Dakle, antidoping odredbe ne predstavljaju de jure ograničenje tržišnog natjecanja prema čl. 101. UFEU-a, iako de facto izričito ograničavaju natjecanje sportaša koji koriste doping. ${ }^{75}$

Međutim, od sadržaja same odluke bitnija je okolnost da navedena odluka predstavlja značajan doprinos u smislu metodološkog pristupa prosudbi (ne) usklađenosti određenog sportskog pravila s odredbama čl. 101. i 102. UFEU-a. ${ }^{76}$ Iz odluke jasno proizlaze tri ključna pitanja o kojima ovisi odgovor na to pitanje. Prvo, može li se sportska federacija koja je donijela određeno pravilo smatrati poduzetnikom ili udruženjem poduzetnika u smislu čl. 101. i 102. UFEU-a. ${ }^{77}$ Drugo, može li se smatrati da pravilo o kojemu je riječ ograničava natjecanje u smislu čl. 101. UFEU-a ili predstavlja zlouporabu vladajućeg položaja u smislu čl. 102. UFEU-a, s ciljem sprečavanja, ograničavanja ili narušavanja tržišnog natjecanja na unutarnjem tržištu. I treće, jesu li, možda, ispunjeni uvjeti za primjenu iznimke, sadržane u odredbi st. 3. čl. 101. UFEU-a.

S obzirom na to da se odredbe europskog prava moraju tumačiti euroautonomno, te da nije dopušteno oslanjanje na istovrsne nacionalne koncepte i tumačenje njihova sadržaja, pri tumačenju pojmova sadržanih u odredbama UFEU-a potrebno je osloniti se na praksu Suda EU. Vezano uz prvo pitanje - može li se sportska federacija koja je donijela određeno pravilo smatrati poduzetnikom ili udruženjem poduzetnika u smislu čl. 101. i 102. UFEU-a, iz prakse Suda EU proizlazi da se poduzetnikom može smatrati „svaki subjekt uključen u ekonomsku aktivnost bez obzira na izvor financiranja“" ${ }^{78}$ pri čemu se ,ekonomskom aktivnošću“"79 smatra svaka aktivnost koja se sastoji od ,pružanja dobara i usluga na tržištu“.80 Odatle slijedi da u sportskom sektoru u ekonomsku aktivnost, ovisno o okolnostima, mogu biti involvirani i sportaši (kao pojedinci) i sportski savezi.

74 Ibidem, paragraf 47

75 Ibidem, paragrafi 42. i 45.

76 Kienapfel, P./Stein, A.: The application of articles 81 and 82 EC in the sport sector, Competition Policy Newsletter, 3, 2007. Dostupno na: http://ec.europa.eu/competition/publications/cpn/2007_3_6.pdf.

77 Vidi: Budzinski, O.: „The institutional framework for doing sports business: principles of EU competition policy in sports markets". International Journal of Sport Management and Marketing, 11 $(1 / 2), 2012$, str. 49

78 Sud EU, Case 41/90 Klaus Höfner and Fritz Elser v Macroton GmbH (1991) ECR I-1979., para. 21. Vidi i: Veermersch, A.: „All's fair in sport and competition? The application of EC competition rules to sport", Journal of Contemporary European Research, 3 (3), 2007.

79 Ekonomska aktvnost koja ima socijalnu svrhu u pravilu se neće smatrati ekonomskom aktivnošću u smislu čl. 101. i 102. UFEU-a. Vidi: C-205/03 P Federacion Española de Empressas de Tecnología Sanitaria (FENIN) v Commission of the European Communities (2006) ECR I-06295. Goulding L.: Is the NHS subject to competition law?, preuzeto sa: http://eutopialaw.com/2013/07/19/is-the-nhssubject-tocompetition-law/, 2013.

80 Sud EU, Case 118/85 Commission v Italy (1987) ECR 2599, para. 7. 
Vezano uz drugo pitanje - može li se smatrati da pravilo o kojemu je riječ ograničava natjecanje u smislu čl. 101. UFEU-a ili predstavlja zlouporabu vladajućeg položaja u smislu čl. 102. UFEU-a, s ciljem sprečavanja, ograničavanja ili narušavanja tržišnog natjecanja na unutarnjem tržištu, potrebno je provesti tzv. "Wouters test" ${ }^{81}$ Radi se o prosudbi utemeljenoj na kriterijima sadržanim u odluci Suda $\mathrm{EU}^{82}$ koja po svom sadržaju nema nikakve veze sa sportskim pravom, ali je od presudnog značaja za tumačenje odnosa sporta i prava tržišnog natjecanja. Odlukom u predmetu Meca-Medina Sud EU je još jednom potvrdio Wouters test. ${ }^{83}$ Iz Odluke se jasno iščitava da pri prosuđivanju sukladnosti pravila donesenih od strane sportskih saveza treba uzeti u obzir: „sveobuhvatan kontekst“ u kojemu je pravilo doneseno ili u kojem proizvodi svoje učinke te njegove ciljeve, jesu li ograničenja uzrokovana tim pravilom ,imanentna organizaciji i pravilnom upravljanju natjecateljskim sportom " ${ }^{84}$ te je li ograničenje uvedeno tim pravilom razmjerno namjeravanom cilju. ${ }^{85} \mathrm{~S}$ obzirom na odredbe Uredbe Vijeća (EZ) br. 1/2003, u slučaju podnošenja individualnog zahtjeva, teret dokazivanja povrede odredaba čl. 101. i/ili 102. UFEU-a leži na podnositelju zahtjeva. ${ }^{86}$

I u odnosu na treće pitanje - jesu li ispunjeni uvjeti za primjenu iznimke sadržane u odredbi st. 3. čl. 101. UFEU-a, koja ostavlja mogućnost da određene vrste sporazuma ili sporazuma među poduzetnicima, odnosno odluke ili vrste odluka udruženja poduzetnika, odnosno usklađenog djelovanja, budu izuzeti od primjene st. 1. čl. 101. UFEU-a, moguće se osloniti na sadržaj odluke Suda EU u predmetu Meca-Medina. Naime, iz navedene odluke proizlazi da se st. 3. čl. 101. UFEU-a primjenjuje onda kad je riječ o pravilu koje nije ,imanentno organizaciji i pravilnom upravljanju natjecateljskim sportom“, ali su njegovi korisni učinci veći od njegovih ograničavajućih učinaka.

Osim u predmetu Meca-Medina, Sud EU je u više navrata odlučivao o usklađenosti sportskih pravila s odredbama prava EU o zabrani sprečavanja tržišnog natjecanja. Radi se o vrlo različitim pitanjima koja je moguće podijeliti u dvije grupe: aktivnosti vezane uz sport koje generiraju prihode te aktivnosti vezane uz organizaciju sporta ${ }^{87}$ U prvu kategoriju spadaju predmeti koji ne zahtijevaju strogu liniju razgraničenja između ,čisto sportskih pravila“ i ekonomske aktivnosti. U toj vrsti predmeta primjenjivost odredaba o zabrani sprečavanja tržišnog natjecanja uopće nije upitna.

81 Tako: Geeraert, op. cit. (bilj. 13), str. 20.

82 Vidi: Sud EU, C-309/99 Wouters (2002) ECR I-1577.

83 Vidi paragrafe 45. i 46. Odluke Suda EU u predmetu Meca-Medina (bilj. 44).

84 European Commission: The EU and Sport: Background and Context, Accoompanying document to the White Paper on Sport, SEC(2007) 935 final.

85 Kienapfel/Stein, op. cit. (bilj. 76), str. 7.

86 Vidi i: Weatheril, S.: „Anti-doping revisited - the demise of the rule of ,purely sporting interst“?", European Competition law Review, 27, 2006.

87 Tako: Mataija, M.: Private Regulation and the Internal Market Sport, Legal Services and Standard Setting in EU Economic Law, Oxford Studies in European Law; Oxford University Press, 2016., str. 170. 
Dr. sc. Ines Medić: Pravni i ekonomski aspekti Pravila UEFA-e o licenciranju klubova i financijskom... Zbornik radova Pravnog fakulteta u Splitu, god. 55, 2/2018., str. 331.- 351.

Riječ je o predmetima koji uključuju prodaju ulaznica ${ }^{88}$ te televizijskih aranžmana. ${ }^{89}$ U drugu grupu spadaju predmeti koji se tiču pravila sportskih organizacija ili, drugim riječima, organizacijskih aspekata sporta. Najčešće uključuju način upravljanja, mehanizme za sprečavanje sukoba interesa i druga postupanja sportskih tijela pri odlučivanju. ${ }^{90}$ Radi se o predmetima koji često uključuju i slobodu kretanja, a koja Komisija također prepoznaje kao potencijalnu ugrozu slobode tržišnog natjecanja. ${ }^{91}$

\section{VI. (NE)SUKLADNOST ODREDABA PRAVILNIKA O LICENCIRANJU KLUBOVA I FINANCIJSKOM FAIR PLAYU S ODREDBAMA PRAVA EU O TRŽIŠNOM NATJECANJU}

Pitanje (ne)sukladnosti odredaba Pravilnika s odredbama prava EU o tržišnom natjecanju pokrenuo je pred Europskom komisijom licencirani nogometni posrednik Daniel Striani, odnosno njegov punomoćnik Jean-Louis Dupont, u svibnju 2013. godine. Striani se pozivao na nesukladnost Pravilnika UEFA-e o licenciranju klubova i financijskom fair playu s pravom tržišnog natjecanja u EU, zbog ograničavanja ulaganja u klubove, ,zaključavanje“ moći u rukama velikih klubova, ograničavanje primanja igrača i ograničavanje transfernih naknada. Tražio je od Komisije istragu o usklađenosti odredaba Pravilnika s odredbama prava EU o zaštiti tržišnog natjecanja, čime je Komisiju stavio u veoma nezgodan položaj s obzirom na to da je Pravilnik donesen uz njezin blagoslov.

U travnju 2014., Komisija je obavijestila Strianija o svojoj namjeri odbacivanja predmeta. Uskoro je to i napravila, uz obrazloženje da se Pravilnik odnosi na klubove, a ne na posrednike te da Striani nema pravni interes za njegovo osporavanje, ${ }^{92}$ a također i da svoj zahtjev može rješavati pred nadležnim nacionalnim sudom. Pored toga, navela je da Strianijeva tvrdnja da će odredbe Pravilnika smanjiti broj transfera nije ničim potkrijepljena te da je Pravilnik na snazi već četiri godine, a da se nitko od adresata nije žalio. Osim toga, da su o Pravilniku unaprijed pregovarali svi relevantni dionici.

Striani je pokrenuo i postupak pred belgijskim sudom, od kojega je zatražio da podnese zahtjev Sudu EU za prethodnim tumačenjem. Belgijski sud, u svibnju 2015., proglasio se nenadležnim. Budući da je sjedište UEFA-e u Švicarskoj, trebalo je primijeniti odredbe Luganske konvencije o nadležnosti i priznavanju te

88 Npr. Distribution of package tours during the 1990 World Cup (Predmeti IV/33.384 i IV/33.378). Commission Decision 92/521/EEC (1992) S1. 1. L 326/31.

89 Npr. Spojeni predmeti C-403/08 i C-429/08 Football Association Premier League Ltd and Others $v$ QC Leisure and Others (C-403/08) i Karen Murphy v Media Protection Servies Ltd. (2011) ECR I-90834.

90 Mataija, op. cit. (bilj. 87), str. 173.

91 Primjerice: C-49/07 Motosykletistiki Omospondia Ellados NPID (MOTOE) v Elliniko DImosio (2008) ECR I-4863, para. 48.

92 Case AT.40105 UEFA Financial Fair Play Rules. Commission Decision rejecting the complaint, C(2014) 8028 final. 
izvršavanju sudskih odluka u građanskim i trgovačkim stvarima, ${ }^{93}$ koje upućuju na nadležnost švicarskog suda. Međutim, sud je odredio privremenu mjeru kojom je UEFA-i naložio da ne ide dalje u provedbi onih odredbi Pravilnika koje idu za daljnjom redukcijom gubitaka, ali i podnio zahtjev Sudu EU za prethodnim tumačenjem valjanosti poduzete mjere. ${ }^{94}$ Predsjednik devetog vijeća odbacio je zahtjev kao nedopušten. ${ }^{95}$ Međutim, to ni u kom slučaju ne treba tumačiti na način da ne postoji nesuglasje s pravom EU o tržišnom natjecanju. Konačna je tek odluka Suda EU.

Naime, s obzirom na ciljeve koje namjerava ostvariti, Pravilnik UEFA-e o licenciranju klubova i financijskom fair playu moguće je promatrati kao horizontalni sporazum između pružatelja usluga (klubova) koji, među ostalim, uključuje posvećenost smanjivanju potrošnje. Međutim, Pravila su ojačana i vertikalnim ograničenjima ${ }^{96}$ koja, kao regulatorno tijelo, provodi UEFA. Kao takva, predstavljaju ograničenje tržišnog natjecanja i protivna su čl. 101. UFEU-a, koji je temeljna odredba Ugovora kojom se kontroliraju ograničavajuće prakse i drugi aranžmani koji limitiraju tržišno natjecanje. Imajući u vidu činjenicu da sportski savezi i federacije zapravo imaju monopolsku poziciju, moguće ih je podvesti i pod odredbe čl. 102. UFEU-a.

Dosadašnja praksa Suda EU pokazuje da se pravo tržišnog natjecanja tumači imajući u vidu kontekstualne nijanse predmeta. Tako je, primjerice, u predmetu Albany International ${ }^{97}$ Sud razmatrao usklađenost kolektivnih ugovora između poslodavaca i zaposlenika s čl. 101. UFEU-a. Sud je zaključio da je ograničenje tržišnog natjecanja svojstveno takvim ugovorima, ali da bi podvrgavanje takvih ugovora - kojima poslodavac i zaposlenici zajednički nastoje doći do rješenja za poboljšanje radnih uvjeta - odredbi čl. 101. UFEU-a značajno ugrozilo ciljeve socijalne politike koji se takvim ugovorima nastoje ostvariti.

Iako navedena odluka zbog činjeničnog supstrata ne predstavlja presedan bitan za tumačenje Pravila, otvara prostora tumačenju koje je za sport veoma bitno, a odnosi se na mogućnost izuzeća od primjene čl. 101. i/ili 102. UFEU-a u slučajevima kad je riječ o pravilu čiji su učinci ,imanentni organizaciji i pravilnom upravljanju natjecateljskim sportom".

U svakom slučaju, odgovor na pitanje o (ne)usklađenosti Pravilnika s odredbama prava EU o tržišnom natjecanju ovisit će o odgovoru na već spomenuta tri pitanja.

93 S1. 1. EU L 147/5, od 30. X. 2007.

94 C-299/15 Daniele Striani and Others v Union européenne des Sociétés de Football Association (UEFA) and Union Royale Belge des Sociétés de Football Association (URBSFA), Zahtjev za prethodnu odluku koji je 19. lipnja 2015. uputio Tribunal de première instance de Bruxelles (Belgija), Sl. 1. EU C 270/19, od 17. VIII. 2015.

${ }_{95}$ C-299/15 Daniele Striani and Others $v$ Union européenne des Sociétés de Football Association (UEFA) and Union Royale Belge des Sociétés de Football Association (URBSFA), Rješenje Suda (deveto vijeće) od 16. srpnja 2015., ECLI:EU:C:2015:519.

96 Pravilima koja se odnose na licenciranje.

97 Sud EU, C-67/96 Albany International BV v Stichting Bedrijfspensioenfonds Textielindustrie (1999) ECR 1-5751. 
Dr. sc. Ines Medić: Pravni i ekonomski aspekti Pravila UEFA-e o licenciranju klubova i financijskom... Zbornik radova Pravnog fakulteta u Splitu, god. 55, 2/2018., str. 331.- 351.

Prvo, može li se sportska federacija koja je donijela određeno pravilo smatrati poduzetnikom ili udruženjem poduzetnika u smislu čl. 101. i 102. UFEU-a. ${ }^{98}$ Drugo, može li se smatrati da pravilo o kojemu je riječ ograničava natjecanje u smislu čl. 101. UFEU-a ili predstavlja zlouporabu vladajućeg položaja u smislu čl. 102. UFEU-a, s ciljem sprečavanja, ograničavanja ili narušavanja tržišnog natjecanja na unutarnjem tržištu. I treće, jesu li, možda, ispunjeni uvjeti za primjenu iznimke, sadržane u odredbi st. 3. čl. 101. UFEU-a.

Kada su u pitanju sportska tijela, kvalifikacija subjekta kao poduzetnika čak je i nešto šira. Naime, prema Mišljenju Komisije u predmetu 1990 FIFA World Cup,${ }^{99}$ prednost je dana aktivnostima FIFA-e koje su ekonomske prirode, kao što su: zaključivanje ugovora o oglašavanju, komercijalna eksploatacija znaka Svjetskog kupa te zaključivanje ugovora vezanih uz prava TV-emitiranja, pa je zaključeno da se FIFA ima smatrati poduzetnikom u smislu čl. 101. UFEU-a. Međutim, iz odluke Suda EU u predmetu Piau ${ }^{100}$ proizlazi da je FIFA-u, kao globalno upravljačko tijelo u nogometu, moguće kvalificirati ne samo kao udruženje poduzetnika u smislu čl. 101. UFEU-a, nego i kao poduzetnika u smislu čl. 102. UFEU-a. Naime, kao krovna federacija, FIFA okuplja nacionalne saveze koji su i sami po sebi udruženje poduzetnika ili pak poduzetnici (primjerice, u situaciji u kojoj se uključuju u prodaju medijskih prava). ${ }^{101}$

Dakle, ovisno o kutu gledanja na stvari, sportske federacije mogu se kvalificirati kao poduzetnik ili kao udruženje poduzetnika, ukoliko su uključene u ekonomske aktivnosti. Međutim, iz odluke Komisije u predmetu vezanom uz Ligu prvaka UEFA-e, ${ }^{102}$ razvidno je da Komisija smatra da se čak i nacionalni sportski savezi (kako predstavljaju savez klubova) mogu smatrati poduzetnikom, ali i udruženjem poduzetnika. ${ }^{103}$ Stoga nam se čini da nema dileme da se UEFA može smatrati bilo poduzetnikom, bilo udruženjem poduzetnika u smislu čl. 101. i 102. UFEU-a. Doduše, Strianijev podnesak temelji se na čl. 101. UFEU-a koji UEFA-u smatra trgovačkim društvom, koje Pravilnikom ograničava klubove u trošenju novca na plaće i transfere. Kako toč. (b) st. 1. čl. 101. UFEU-a izrijekom zabranjuje sporazume koji limitiraju ili kontroliraju investicije, pravilo o „točki pokrića“ moglo bi se promatrati kao nezakonito ograničavanje investicija od strane udruženja poduzetnika (UEFA-e), iako odredbe Pravilnika iz formule za izračunavanje „točke pokrića“ zapravo isključuju troškove koji stvaraju dugove. Takvo postupanje ima

98 Vidi: Budzinski, op. cit. (bilj. 74), str. 49.

99 Vidi bilj. 85.

100 Sud EU, C-171/05 Laurent Piau v Commission (2006) ECR I-37.

${ }^{101}$ Ibidem, para. 71-72.

102 European Commission, Case 37398 Joint selling of the commercial rights of the UEFA Champions League, OJ L 291/25, 2003., para. 106.

${ }^{103}$ I sportaši pojedinci pod određenim uvjetima mogu se kvalificirati kao poduzetnici. Više o tome vidi u: Zardini Filho, C.E.: „European Union Competition Law in Sports: Cases and relevant Aspects of Articles 101 and 102 of the Treaty na the functioning of the European Union, their importance and influence on sport Managers and Institutions“, PODIUM Sport, Leisure and Tourism Review, Vol. 6, N. 4, Setembro/Dezembro 2017., str. 398. 
smisla jer dug potiče tržišno natjecanje i predstavlja legitimnu strategiju financiranja produktivnog i profitabilnog ulaganja.

U slučaju da se pozvao na čl. 102. UFEU-a, situacija bi bila nešto složenija jer bi trebalo dokazati dominaciju na „relevantnom tržištu“ (tržištu proizvoda). Prema stajalištu Komisije, tržište proizvoda sastoji se od „svih proizvoda i/ili usluga koje se smatraju razmjenjivima i zamjenjivima u odnosu na potrošača, zbog svojih karakteristika, svoje cijene i namjeravane upotrebe“ “. ${ }^{104}$ Temeljno je pitanje postoji li zamjena za taj proizvod. Kad je riječ o UEFA-i, tržištem proizvoda mogu se smatrati europska nogometna natjecanja. S obzirom na to da, pored onih koje organizira UEFA, ne postoje druga europska nogometna natjecanja, ne postoji niti zamjena za taj proizvod.

Nadalje, vezano uz čl. 101. st. 1. UFEU-a, potrebno je uočiti njegovu tripartitnost. ${ }^{105}$ Prvo, potrebno je dokazati da postoji neka vrsta povezanosti među poduzetnicima. Drugo, ta povezanost mora ugrožavati trgovinu među državama članicama i treće, sporazum mora ,imati za cilj ili proizvoditi učinak ograničavanja tržišnog natjecanja na unutarnjem tržištu“. Imajući u vidu da Pravilnik obvezuje sve klubove koji se natječu na natjecanjima UEFA-e, moguće ga je smatrati ugovorom među poduzetnicima. Što se tiče utjecaja na trgovinu među državama članicama, ne traži se da sporazum u danom momentu zaista i utječe na trgovinu među državama članicama, dostatno je i da ima takav potencijal. Budući da je UEFA regionalna organizacija unutar koje klubovi redovito međusobno posluju, vrlo je malo vjerojatno da Pravilnik neće imati utjecaja na trgovinu među državama članicama. Konačno, čak i površnim uvidom u sadržaj odredbi Pravilnika, lako je uočiti da isti ima za cilj ograničiti tržišno natjecanje na unutarnjem tržištu. Iz dosadašnje prakse Suda EU dade se zaključiti da bi i Sud bio istog mišljenja. ${ }^{106}$ Vezano uz prosudbu eventualnog učinka na tržište, nesporno je da će inzistiranje na „točki pokrića“ i ograničavanje investiranja u klubove od strane vlasnika proizvoditi tržišno relevantne učinke: „cementira“ postojeće stanje te znatno otežava prelazak iz jedne u drugu kategoriju, umjetno ograničava cijenu transfera, kreira se tzv. „tržište oligopola“, ograničavanjem plaća igrača utječe se na mogućnost angažiranja novih igrača, a time i na kompetitivnost itd.

Čl. 101. st. 3. UFEU-a predviđa dvije vrste iznimki. Prva se odnosi na vertikalne sporazume. Pravila je svakako moguće promatrati kao horizontalni sporazum između pružatelja usluga (klubova) koji, među ostalim, uključuje posvećenost smanjivanju potrošnje. Međutim, ona su ojačana i vertikalnim ograničenjima ${ }^{107}$ koja, kao regulatorno tijelo, provodi UEFA. Pitanje je, međutim, bi li Sud Pravilnik kvalificirao kao horizontalni i/ili vertikalni sporazum. Ukoliko bi ga karakterizirao

\footnotetext{
104 Commission Notice 97/C372/03 OJ C 372, 1997.

105 Više o tome vidi u: Kaplan, V., „UEFA financial Fair Play Regulations and European Union Antitrust Law Complications“, Emory International Law Review, Vol. 29, 2015., str. 815.-839.

106 C-403/08 Football Association Premier League Ltd and Others v QC Leisure and Others (2011) ECR I-90834.

107 Pravilima koja se odnose na licenciranje.
} 
kao vertikalni sporazum, trebao bi utvrditi ima li dominantnu ulogu na relevantnom tržištu. Imajući u vidu da se Pravilnik odnosi na većinu europskih klubova, teško je povjerovati da bi mogao profitirati od ove iznimke. Druga se iznimka odnosi na taksativno navedene uvjete koji bi trebali biti ispunjeni, međutim, nisu, pa se niti na tu iznimku nije moguće pozvati.

U odnosu na čl. 102. UFEU-a, kontroliraju se tri elementa: prvi, konkretno ponašanje pojedinačnog poduzetnika u dominantnoj poziciji; drugi, postotak tržišta koje pokriva te treći, zlouporaba vladajuće pozicije. ${ }^{108}$ Različite ekonomske aktivnosti same UEFA-e ostavljaju dovoljno prostora da je se kvalificira kao pojedinačnog poduzetnika. ${ }^{109}$ Što se tiče utvrđivanja dominantne pozicije na tržištu, to će ovisiti o kvalifikaciji Pravilnika kao horizontalnog ili vertikalnog sporazuma. Kao horizontalni sporazum UEFA-e, koji se primjenjuje u suradnji s nacionalnim savezima, Pravilnik nedvojbeno dominira europskim tržištem i kao takav je protivan čl. 102. UFEU-a. Međutim, kao vertikalni sporazum može i ne mora biti kvalificiran kao tržišno dominantan iz razloga što je UEFA-u, zbog ekonomske nezavisnosti nacionalnih saveza, moguće smatrati i pojedinačnim poduzetnikom.

Što se tiče drugog uvjeta, već je prije bilo govora o tome da Pravilnik pokriva veći dio relevantnog tržišta.

I konačno treći uvjet, utvrđivanje zlouporabe vladajuće pozicije. Prema stajalištu Komisije iz 2005. godine, ${ }^{110}$ istražuje se potencijalno antikompetitivno ponašanje te iz toga proizašla šteta. Uvjetujući tko i pod kojim uvjetima može igrati na natjecanjima UEFA-e, Pravilnik utječe i na položaj kluba u nacionalnom poretku. U kombinaciji s geografski uvjetovanom raspodjelom sredstava od medijskih prihoda, šanse malih klubova za dostizanjem točke pokrića iznimno su slabe. Međutim, s obzirom na to da su pristali na odredbe Pravilnika, mali klubovi ne bi imali pravo na izravno podnošenje tužbe, iako ih dominacija većih nacionalnih saveza na tržištu ugrožava, a odredbe Pravilnika čine nekompetitivnima.

\section{EKONOMSKI UČINCI PRAVILA O FAIR PLAYU}

Kao i svaki drugi normativni akt, i Pravilnik UEFA-e o licenciranju klubova i financijskom fair playu imao je za cilj postići određene učinke. Pored zaštite integriteta igre, ekonomski cilj bio je osigurati dugoročnu financijsku stabilnost klubova. Stoga ne čudi da upravo taj ekonomski element predstavlja središnji element Pravilnika.

108 Više o tome vidi u: Kaplan, op. cit. (bilj. 105), str. 839.- 850.

109 Npr. organizacija europskih natjecanja, kontrola nagradnog fonda, kontrola medijskih prava itd.

${ }_{110}$ Gual, J. et al.: Report by the EAGCP: An Economic Approach to Artcle 82, Econ. Advisory Group on Competition Policy of the European Community, 2 July 2005. 
Iako, prema Mülleru, financijski doping ugrožava integritet sporta i stoga na dulje razdoblje potencijalno ugrožava njegovu popularnost i održivost, ${ }^{111}$ zahtjev za „točkom pokrića“ nedvojbeno ograničava natjecanje i kontrolira primanja igrača uvođenjem tzv. ,mekog““ (soft) salary capa ${ }^{112}$ Kako europski model sporta počiva na bitno različitim temeljima u odnosu na američki, to će, dugoročno, dovesti i do nekih neželjenih posljedica.

Za početak, utjecat će na „cementiranje“ postojećeg stanja te znatno otežati prelazak iz jedne u drugu kategoriju. ${ }^{113}$ Učinkovitim zamrzavanjem postojeće financijske pozicije europskih nogometnih klubova, pravilo „točke pokrića“ dovodi do narušavanja, a ne poticanja tržišnog natjecanja, što je upravo obrnuto od načela kojim se vodi, načela pravednosti. Kreira tržište tzv. „oligopola“, tj. velikih financijski zdravih klubova koji sudjeluju u natjecanjima UEFA-e. ${ }^{114}$ Oni će i dalje uživati u čvrstoj poziciji u privlačenju novih igrača. To zapravo znači da će jaki ostati jaki, a slabi ostati slabi. Ojačava se status quo. U tome nema ničega što bi dugoročno privuklo i zadržalo navijače klubova slabije lige.

Potrošači su, naravno, više zainteresirani za praćenje boljih klubova. To utječe i na određivanje cijene ulaznica, pretplata, na trgovinu, sponzorstvo, zaradu od medijskih prava itd., čime se dodatno povećava financijska neravnopravnost. Umjetno se ograničava cijena transfera i stvara „umjetni plafon“ koji ne odražava volju vlasnika za ulaganjem u jačanje tima. Rezultat će biti manje transfera, s nižim iznosima. Manji je i broj posrednika u prilici poslovati. ${ }^{115}$ Sve navedeno značajno utječe na tržišne uvjete jer je mogućnost natjecanja bitno ograničena. ${ }^{116}$

\section{ZAKLJUČAK}

Razloge uvođenja Pravilnika najbolje opisuju riječi Michela Platinija: „Brojni klubovi diljem Europe koji uspijevaju poslovati na održivoj bazi ... imaju nezamislivih poteškoća u natjecanju s klubovima koji stvaraju troškove i plaćaju transferne naknade daleko iznad svojih mogućnosti, a iz godine u godinu prijavljuju troškove“. ${ }^{117}$

111 Müller, C. et. al.: „The financial fair play regulations of UEFA: an adequate concept to ensure the long-term viability and sustainability of European Club Football?", International Journal of Sport and Finance, 7(2), 2012., str. 117.

112 Više o tome, i o razlici u odnosu na tzv. ,hard salary cap“, vidi u: Lindhom, J.: The problem with salary caps under European Union Law: the case against Financial Fair Play, 2010., str. 190.

113 Petit tu pojavu naziva i „okoštavanjem“. Petit, N.: „,Financial Fair Play “ or an „oligopoleague“ of football clubs?, Oxera Agenda, July 2014.

114 Vidi: Serby T: The state of EU sports law: lessons form UEFA's Financial Fair Play' regulations, International Sports Law, vol. 16, 2016., str. 47.

115 Kaplan, op. cit. (bilj. 105), str. 828 i 829.

116 Više o tome vidi u: Vöpel, op. cit.. (bilj. 15), str. 9.-19.

117 UEFA (2008.). 
Dr. sc. Ines Medić: Pravni i ekonomski aspekti Pravila UEFA-e o licenciranju klubova i financijskom... Zbornik radova Pravnog fakulteta u Splitu, god. 55, 2/2018., str. 331.- 351.

S ciljem uspostavljanja financijske stabilnosti klubova te natjecateljske ravnoteže, UEFA je u 2010. predstavila Pravilnik o licenciranju klubova i financijskom fair playu. Navedenim se Pravilnikom uvelo poslovanje na „točki pokrića“ te time u znatnoj mjeri utjecalo na takvu politiku klubova. Većina odredbi je uspješno implementirana i od strane klubova i nacionalnih saveza do sada nije bilo pritužbi. Međutim, nisu svi učinci Pravilnika nužno pozitivnog predznaka. Pokazalo se, naime, da i pravni i ekonomski učinci nerijetko imaju neočekivani efekt, osobito u kombinaciji s pravom EU.

Koliko god UEFA nije oduševljena ograničavanjem autonomije sporta pravom EU, njegovu primjenu nije moguće izbjeći. Tako, i što se pravnih učinaka tiče, temeljno je pitanje je li Pravilnik kompatibilan s pravom EU. ${ }^{118} \mathrm{U}$ tom smislu još uvijek se čeka odluka Suda EU koja bi razjasnila određena sporna pitanja. Za sada je, zbog proceduralnih razloga, ta prilika propuštena.

Za razliku od ekonomskih učinaka, utjecaj Pravilnika na solidarnost i natjecateljsku ravnotežu nije tako lako razabrati. ${ }^{19}$ Ono što je očito jest da Pravilnik smjera k uspostavljanju europskog javnog prostora. ${ }^{120}$ Što se natjecateljske ravnoteže tiče, očekivanje da će, u nemogućnosti oslanjanja na vlasnike kao izvor financiranja, klubovi koji se od početka više oslanjaju na vlastite snage imati više šanse za pobjedu, čini se, ipak nije puno vjerojatno. Vjerojatnije je da će klubovi morati potražiti drugi izvor povećanja vlastitih prihoda što može rezultirati povećanjem cijene ulaznica i sl. ${ }^{121}$ Međutim, postoji i opasnost od stvaranja dvostrukog kolosijeka, gdje klubovi koji odluče da neće sudjelovati u natjecanjima koja organizira UEFA nisu podložni niti financijskom nadzoru. ${ }^{122}$ To može utjecati na stvaranje zatvorenih liga i tako dodatno zacementirati postojeće stanje. Unatoč tome, načelo osamostaljivanja klubova u odnosu na bogate vlasnike, ako je uspješno implementirano, može se smatrati značajnim postignućem u upravljanju klubovima. ${ }^{123}$

Sve u svemu, nije moguće osporiti činjenicu da je, zahvaljujući Pravilniku, financijsko zdravlje europskog nogometa u cjelini bitno poboljšano. ${ }^{124}$ Unatoč znatno strožim uvjetima, velik broj klubova i dalje sudjeluje u europskim natjecanjima. Ipak, neki ekonomisti upozoravaju na činjenicu da su određene studije pokazale

118 Garcia, B.: „UEFA and the European Union: From Confrontation to Co-operation“, Journal of Contemporary European Research, Vol. 3. No. 3., 2007, str. 217.-218.

119 Iako ima različitih pokušaja. Vidi: Preuss, H./Haugen, K.K./Schubert, M.: „UEFA financial fair play: the curse of regulation", EJSS Journal, 2(1), 2014.

${ }^{120}$ Hill, J.: „UEFA ad the European Unioon: the green shoots of a new European public space?“", u: Niemann, A./Garcia, B./Grandt, W. (eds.), The Transformation of European Footbll: Towards a Europeanisation of the National Game, Manchester University Press, 2011., str. 52.

${ }^{121}$ Conn (2011.), op. cit. (bilj. 75).

122 Tako: Geey, D.: „,The UEFA FInancial Fair Play Rules: a difficult balancing act“, Entertainment and Sports Law, vol. 9, no. 1, 2011.

123 Conn, D.: „Just how Fair is Platini’s Financial Fair Play?“, The Guardian - Sport, no. 25, May 2011., str. 5 .

124 Tome su svakako doprinijele i sankcije. Vidi: Moore, J.: UEFA's Financial Fair Play Regulations: Neymar, Mbappe and PSG 's transfer policy - ,Financial Doping “ or Market Forces?, preuzeto sa: http:// www.natlawreview.com. 
da je „hard salary cap“, po uzoru na Ameriku, učinkovitija metoda uvođenja reda na sportska tržišta. ${ }^{125} \mathrm{~S}$ obzirom na to da europski model sporta počiva na bitno različitim temeljima u odnosu na američki model sporta, pitanje je bi li spomenuti model bio jednako učinkovit i u europskom kontekstu.

\section{LEGAL AND ECONOMIC ASPECTS OF UEFA'S RULES ON LICENSING OF CLUBS AND FINANCIAL FAIR PLAY.}

The results of supervision which UEFA in 2009 carried out on clubs showed that more than half of a total of 655 European clubs are in debt. Moreover, these are huge debts which are disproportionate with their financial possibilities. The three biggest European clubs were in such financial disarray that they were in two years, treated like other businesses, declared to be bankrupt. That period coincided with the widening of EU legislative powers and in sport issues and with the focus of the Commission on "sound management". In 2010, UEFA presented a new Rulebook on the licensing of clubs and financial fair play. This Rulebook introduced doing business on "point of financial security" as their basis for the financial sustainability of European clubs. However, from the very beginning of its application its relation with EU legal regulations on competitiveness was disputable. This Rulebook existed in this limbo for 8 years and slowly real effects of its application are starting to be supervised. Namely legal and economic effects were often shown to have an unexpected effect, especially in combination with EU law. The intention here is to observe in detail the Rulebook's regulations through various prisms: relation to EU legal regulations, its economic effects and the effect on stability and competitive balance.

Key words: Eu law, market competitiveness, sport autonomy, UEFA, financial fair play

${ }^{125}$ Szyimanski, op. cit. (bilj. 30). 